DOI: https://doi.org/10.15407/techned2018.05 $\leq \underline{022}$

\title{
INFLUENCE OF THE DENSITY INCREASING OF CLOSE LOCATED WATER MICRO-INCLUSIONS ON ELECTROPHYSICAL PROCESSES IN NONLINEAR SOLID DIELECTRIC
}

$\quad$ Journal
Publisher
ISSN
Issue
Pages

\author{
Tekhnichna elektrodynamika \\ Institute of Electrodynamics National Academy of Science of Ukraine \\ 1607-7970 (print), 2218-1903 (online) \\ No 5, 2018 (September/October) \\ $22-25$
}

\section{Author}

\section{M.A. Shcherba*}

Institute of Electrodynamics National Academy of Sciences of Ukraine, pr. Peremohy, 56, Kyiv, 03057, Ukraine, e-mail: m.shcherba@gmail.com

* ORCID ID : http://orcid.org/0000-0001-6616-4567

\section{Abstract}

Some features of the electro-physical processes that arise in solid dielectric media with the presence of water under the action of strong electric fields are determined. On the example of cross-linked polyethylene insulation of superhigh-voltage cables, the amplifications of the electric field, the increase in current densities and the rise of surface forces in the local regions of the insulation with increasing density of close located water micro-inclusions are calculated. Using the developed mathematical model on the basis of the finite element method, the dependences of the abovementioned values on the number and mutual distances between 
inclusions are determined. It is demonstrated that the fragmentation of micro-inclusions (i.e. an increase in their number with an unchanged total volume of water) increases the stressed volume of the dielectric, as well as the number of areas with increased field strength and pulsating forces. An increase in the field disturbance can also be caused by a change in the configuration of a set of close located inclusions, in particular, with a decrease in the distances between them. The fragmentation of micro-inclusions is dangerous process for a dielectric, since it can lead to further combining the fragmented micro-inclusions into a single conducting structure along the field and results in irreversible degradation of the dielectric. References 12 , figures 3.

Key words: electric field, XLPE insulation, superhigh-voltage cable, water micro-inclusions, electric current, surface forces, stressed volume.

Received: 02.03 .2018

Accepted: 15.03 .2018

Published: 16.08 .2018

\section{References}

1. Shcherba A.A., Podoltsev A.D., Kucheriava I.M. Electromagnetic processes in $330 \mathrm{kV}$ cable line with polyethylene insulation. Tekhnichna Elektrodynamika. 2013. No 1. Pp. 9-15. (Rus) 2. Wang W., Tao W., Ma Z., Liu J. The mechanism of water tree growth in XLPE cables based on the finite element method. Proc. IEEE Intern. Conf. on High Voltage Engineering and Application (ICHVE), Chengdu, China, 19-22 September 2016. Pp. 1-4.

3. Shcherba M.A. Multi-physical processes during electric field disturbance in solid dielectric near water micro-inclusions connected by conductive channels. IEEE Intern. Conf. on Intelligent Energy and Power Systems 
(IEPS), Kyiv, Ukraine. 2016. Pp. 1-5.

4. Kurihara T., Okamoto T., Hozumi N., Miyajima K., Uchida K. Evaluation of relationship between residual charge signal and AC breakdown strength of water-tree degraded XLPE cables removed from service using. IEEE Trans. on Dielectrics and Electrical Insulation. 2017. Vol. 24(1). Pp. 656-665.

5. Podoltsev A.D., Kucheriava I.N. Multiphysical modeling of electrical devices. Tekhnichna Elektrodynamika . 2015. No 2. Pp. 3-15. (Rus)

6. Burkes K.W., Makram E.B., Hadidi R. Water Tree Detection in Underground Cables Using Time Domain Reflectometry. IEEE Power and Energy Technology Systems Journal. 2015. Vol. 2(2). Pp. 53-62.

7. Shcherba M.A., Zolotarev V.M., Belyanin R.V. The comparison of electric field perturbations by water inclusions in linear and nonlinear XLPE insulation. IEEE Intern. Conf. on

Computational Problems of Electrical Engineering

(CPEE), Lviv, Ukraine. 2015. Pp. 188-191.

8. Tokoro T., Nagao M. and Kosaki M. High Field Dielectric Properties and ac Dissipation Current Waveforms of Polyethylene Film. IEEE Trans. on Electrical Insulation. 1992. Vol. 27. No 3. Pp. 482-487.

9. Boggs S.A. Semi-empirical high-field conduction model for polyethylene and implications thereof. IEEE Trans. on Dielectrics and Electrical Insulation. 1995. Vol 2.1. Pp. 97-106.

10. Landau L.D., Livshitz E.M. Electrodynamics of continuous media. Moskva: Fizmatlit, 2003. 560 p. (Rus)

11. Shcherba M.A. Force interaction between close placed conducting micro-inclusions in dielectric medium in external electric field. Tekhnichna Elektrodynamika. 2012. No 3. Pp. 11-12. (Rus)

12. Comsol Inc. Burlington, MA. URL: https://www.comsol.com (Accessed at 15.12. 2017). 